日本臨床麻酔学会第 37 回大会シンポジウム 日臨麻会誌 Vol.39 No.3, $350 \sim 355,2019$

手術室運営 効率化と安全性 : 医療経済学の観点から

周術期の安全と効率化における取り組み

佐和貞治*

[要旨] 術前入院期間の短縮や質の高い術前管理を目指して術前診察を通院外来レベルで行う術前 麻酔科外来方式による術前管理は一般的となった. 一方で, 高難度新規医療技術や保険適用外手術 の導入，ハイリスク高齢者手術の麻酔など，多様な麻酔対象症例に対して医療安全上の観点から適 切なインフォームド・コンセントの提供が求められている. それには説明・同意書の準備, 印刷, 署名, スキャン保存など多くの作業ステップが求められる. 病院情報システムと麻酔管理支援シス テムとの連携の観点から効率よく行うための工夫について，デジタルペーパー ${ }^{\mathrm{T}}{ }^{2}$ (Sony 社)を導入 し効率化を図ったわれわれの施設の取り組みを紹介する.

キーワード : 麻酔術前外来, デジタルペーパー, インフォームド・コンセント, 術前管理, 医療安 全

\section{はじめに}

超高齢化社会の進行や国民医療費の増大という医 療を取り巻く厳しい社会情勢の中で, 麻酔科が関わ る診療業務の形態も変化が求められている。特に, 麻酔科医の行う術前業務に関して, 患者通院レベル で麻酔術前外来に集約化して行う方式が本邦におい ても広まった。術前外来方式は, 集約的に患者診察 や問診, 術前検査データのチェックを効率よく行え ることや，術前評価に一定の質が担保できることな どに加えて, 患者の術前管理に関して, 術前外来担 当の麻酔科が司令塔的な役割を果たすことで，より 安心安全な医療提供に寄与できるという利点があ る。また, 術前評価が麻酔科医にとって日勤の診療 業務として認知される点において, 麻酔科医の QOL にも寄与してきた。 さらに，医療倫理・医療安全の

*京都府立医科大学麻酔科学教室
観点からも，麻酔科が行う医療行為に対して事前に インフォームド・コンセント (IC) を取得すること も, 術前外来にて集約的に行うことで, 個々の麻酔 科医の負担軽減につながっている。

麻酔科が行う術前外来の役割は，的確なリスク評 価を行い, ICを取得し, 安全な麻酔管理につなげ ていく上でますます重要性が増している。平成 30 年度診療報酬改定の中でも, 麻酔管理料の引き上げ が行われ，常勤麻酔科医の行う術前術後の管理を含 めた評価をする流れへの改革が示された。さらに, 身体的・社会的・精神的背景を含めた患者状態の把 握, 栄養状態の評価や持参薬の確認などを含めた入 院時支援加算や口腔衛生管理加算の適用拡大なども 加わり, 入院前から入院術前管理までの多職種によ る総合的な対応に医療コストをかけることで，早期 離床・早期退院の流れを促進していく方向に診療報

\footnotetext{
著者連絡先 佐和貞治

奢 602-8566 京都府京都市上京区河原町通広小路上儿 梶井町 465

京都府立医科大学麻酔科学教室
} 


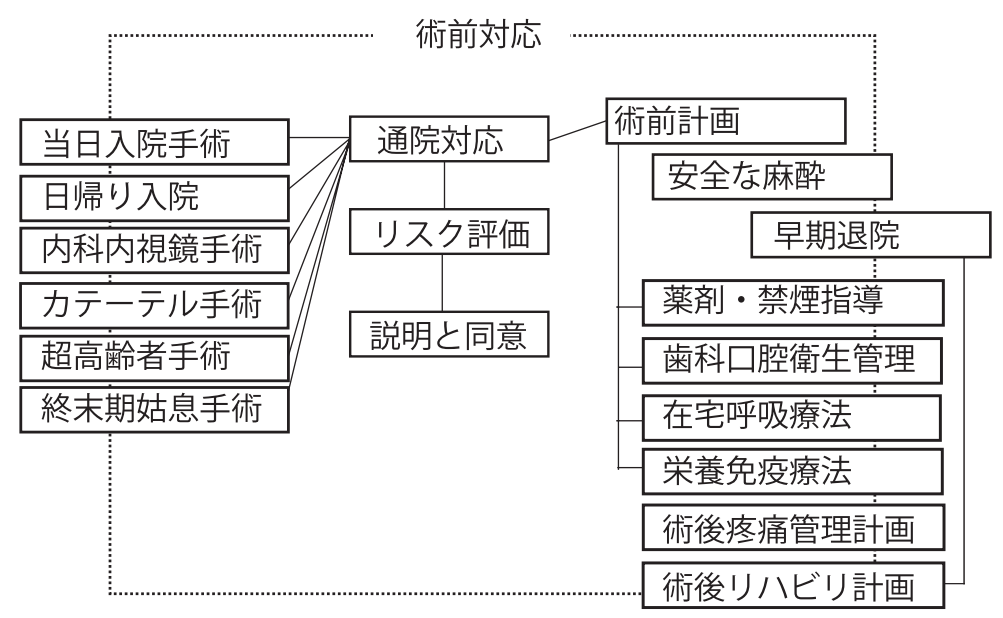

図1多様化する手術実施形態と麻酔術前外来の役割

酬改定が進められている(図1)。これらの流れに対 応するべく, 口腔衛生ケアや持参薬センターなどを 取り込んだ周術期センターの開設などの病院全体で の効率化・集約化が急速に求められる状況にある (図2)。一方で, 手術の麻酔業務だけでも相当に多 忙な状況において, 術前外来へ割り当てられるマン パワーにも限界があり, 効率良い麻酔術前外来の運 用が強く求められている。特に，医療安全の観点か ら, 医療法の改正に基づく平成 27 (2015) 年からの 医療事故調査制度の施行，そして，平成 28(2016) 年の医療法施行規則一部改正に基づく特定機能病院 承認要件見直しに伴う患者に対する適正な IC の提 供は，侵襲的な医療行為を行う麻酔・麻酔関連医療 行為の施行には必須であり, 術前業務の中では最も 時間と労力がかかる点でもある. 今回, 安全で効率 良い術前管理業務を術前外来で展開するために必要 となる周辺要因について, 著者らの取り組みを交え てまとめる。

\section{HIS とAIMSの連携構築}

麻酔術前業務を効率的に行う上で, 病院情報シス テム (HIS ; Hospital Information System) と, 麻酔 管理支援システム (AIMS ; Anesthesia Information Management System)の連携が重要となる. HIS は,

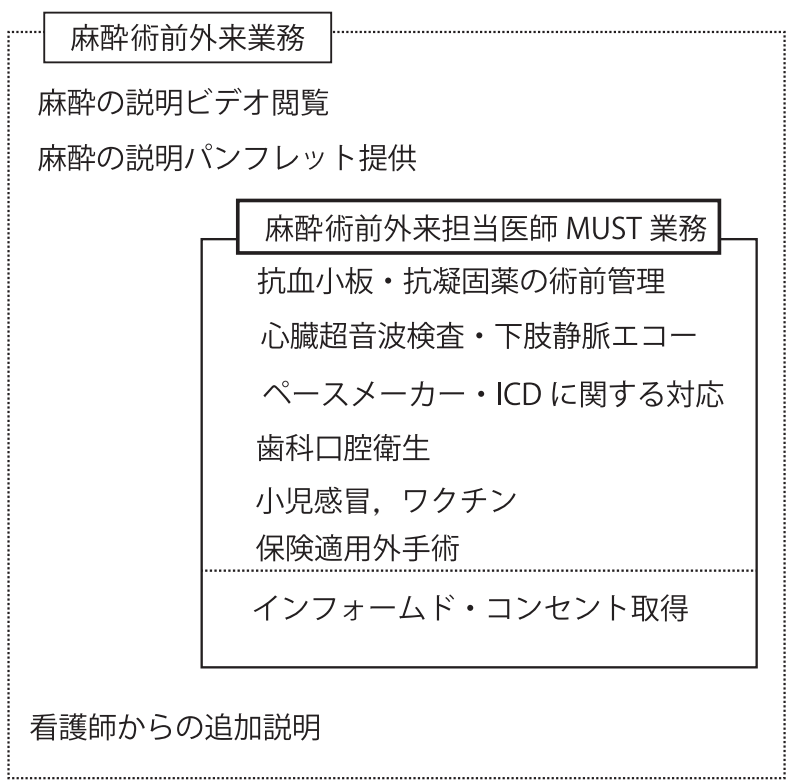

図2 麻酔術前外来での業務フローの概略

麻酔術前外来の業務では，術前投薬内容や所見，追 加検査の必要性を見落とすことで手術が延期になっ たり, 手術や麻酔の危険性が高まる事項については, 麻酔術前外来担当医師が見過ごさないように「MUST 業務」として業務フローを効率よく組み立てること が重要である。

(1)患者受診システム：患者が病院に来院時に受付す る機器など，(2)会計システム：医療費の計算，(3)才 ーダリングシステム : 薬の処方から検査予約, (4)電 子カルテ：患者の診療録の記載など，(5)入退院管理 


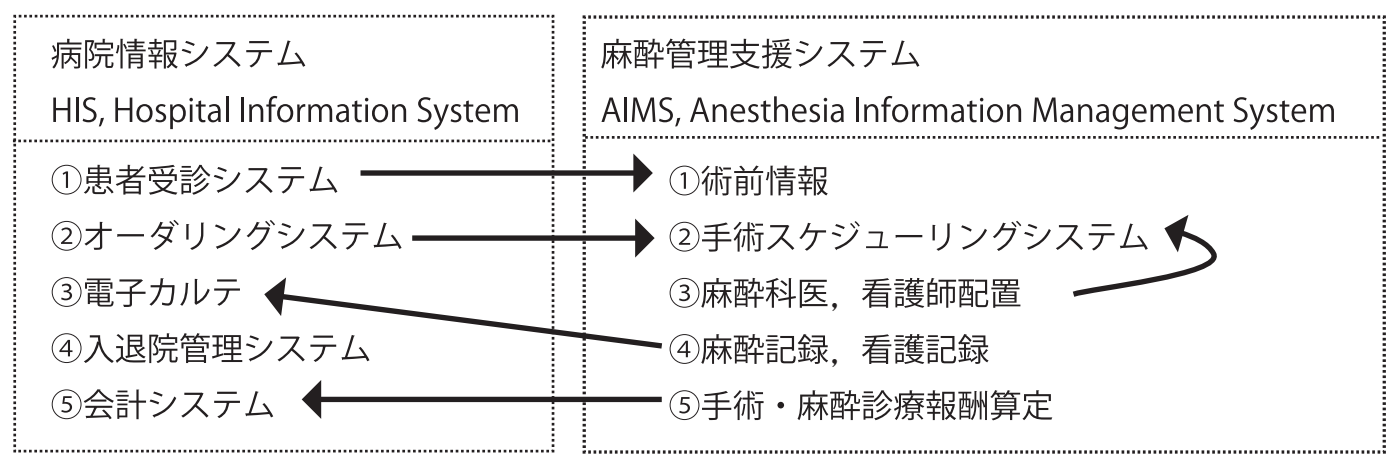

図3 病院情報システム (HIS) と麻酔管理支援システム (AIMS) との複雑な連携

麻酔科の行う術前業務は，病院情報システム (HIS) と麻酔管理支援システム (AIMS)の電子的な連 携構築の中で効率化が図られている.

システム：入退院する患者の情報を管理，などの病 院全体が関わる業務を統合的に管理するコンピュー タシステムである。一方，より専門性が高く，部門 としての特殊性を考慮したソフトウェア上の対応が 求められる中央手術部や，集中治療部などでは，部 門システムと呼ばれる独立したコンピュー夕管理を 利用した管理が普及している。特に麻酔領域におけ るソフトウェア支援システムは麻酔管理支援システ ム (AIMS) と呼ばれる。麻酔術前外来を効率的に運 用し，医療安全性の向上にもつなげるためには， HIS とAIMS の連携構築が重要である(図3).

麻酔科が行う術前業務に通院レベルで対応するた めには, 病院全体の HIS に組み込まれている他科対 診等の電子診療システムを用いることが望まれる. 一方で, 麻酔電子記録を中心として周術期の管理を 集約的に行うAIMSからは, 術前管理に関わる患者 情報が整理された形で提供される。したがって，外 来部門で評価・問診・診察した結果は, HISに収め られると同時に AIMSに連動して漏れなく情報が保 存される必要がある。麻酔科の術前業務が外来に移 行する過程において, かつて多くの HISやAIMSの ベンダーでは, 手術申し込みが外科系診療科から行 われて初めて, 麻酔業務が開始するというような古 い管理方式に基づくソフトウェア構築が行われてい た。外来受診の段階では, 手術日は未定であったり,
また手術そのものも確定していないこともあり，麻 酔科に相談があって, 而術能等に関しての評価を得 たのちに，手術・手術日が決定され，手術申し込み がなければ，術前管理の記録も起動できないような ものもあった，麻酔科の術前業務は，通院レベルで 各科が手術適応を考えて, 当該患者を麻酔科外来に 紹介した時点で開始する。診察や説明を行った内容 に関しては，主治医と HIS を通じて共有するととも に，個々の麻酔科医が漏れなく把握できるように AIMS に保存される必要がある。最低限の HIS-AIMS の連携として必要であることは，外来患者の他科対 診システム患者受診リストに連動した AIMS の術前 管理が可能となることであろう。理想的には, AIMS の術前管理情報画面には, 術前検査結果(胸部 X線 写真, 心電図, 呼吸機能検査, 血液検査など) や, 薬剂の管理情報などが統合的に閲覧できるようにな っていてほしいが，本邦においてはいまだそのよう な状況にはない，HISを開いて各情報を宝探しのよ うに探し当てる作業に多くの時間が割かれている.

\section{II 麻酔術前外来での業務について}

麻酔術前外来での業務は, 術前検査データの確認, 問診によるチェックと禁煙指導などの術前介入，診 察による問題点把握 (手術部位の確認, 歯牙の状態, 挿管困難度評価など）と, 麻酔法の大まかな決定と 
説明，そして医療行為に対するIC 取得である。術 前外来では，一般的な麻酔の説明には，できるだけ ビデオやパンフレットで提供できるようにし,一方, もし対応がされないと手術が直前に延期となったり するような項目 (MUST 業務)への介入が大事であ る(表 1). 中でも血栓塞栓症に対する対応では, 必 要な検査, 抗血小板・抗凝固薬に対する服薬継続 中止指示あるいは代替療法の検討等について, 主治 医と麻酔科医の間で, 個々の患者ごとにコンセンサ スを得ておく必要がある。またペースメーカーや植 え込み型除細動器, 歯科口腔衛生など, 他部門の業 務を求めるような事項に関しても，あらかじめ取り 決めに沿った対応が必要であろう。小児のワクチン 接種についても適応年齢の患児に対して注意してお く必要がある。また患者の自己負担を伴う保険適用 外手術などへの対応について, 意識を高めておく必 要がある.

\section{IIIIC 取得(デジタルペーパーの利用)}

麻酔術前外来の重要な役割として, 患者および患 者家族からの麻酔ならびに関連する侵襲的医療行為 （区域麻酔, 中心静脈路確保, 経食道超音波検査など) に関するIC 取得がある。限られた時間の中で，年 間 5,000から 10,000 件の麻䣫症例に対応するために は，最低でも 1 日あたり平均 $20 \sim 40$ 名に対応する 必要がある。高齢化社会や高度先進医療の背景を受 け，患者は大きな問題のない場合と，複数の併存症 を抱える高いリスクを保つ場合と二極化する傾向に ある。リスクの低い患者に対応する時間を短縮し， 高リスク患者により長い時間配分を行う割り切った 対応も必要となる。そのために, 医師の説明以外に, 1)麻酔に関する説明のビデオ閲覧，2)麻酔を受けら れる方へのパンフレットの配布，3) 看護師による追 加の説明などを組み合わせて，麻酔に対する総合的 な理解を深められるように工夫が必要である。また 手術室看護師の麻酔術前外来への参画により, 看護 師に補助的な説明を担当してもらうことも有効であ
表1 術前チェック：MUST 業務(例)

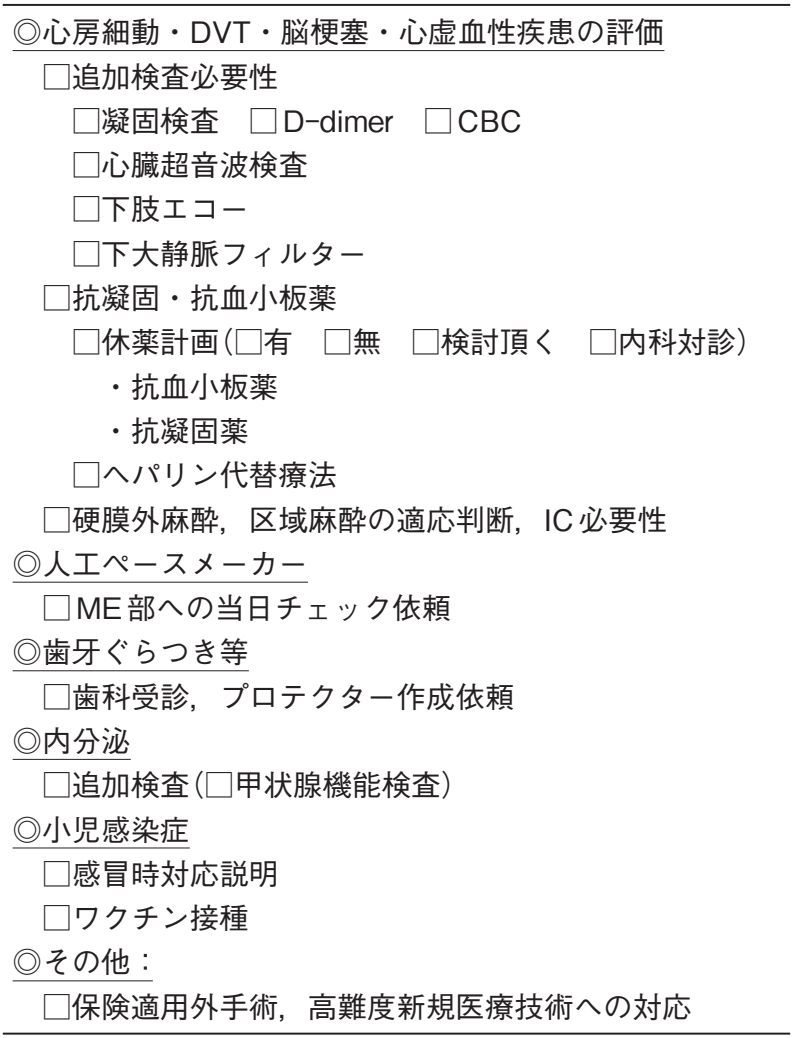

る.

IC 取得に関わる業務フローを効率よく構築する ために，電子カルテや麻酔管理支援システムAIMS との連携を効率よく設計する必要がある。一方で, 説明書や同意書などは，(1)事前に電子的にテンプレ 一ト等を利用して個別作成した書面を印刷し，(2)紙 ベースで患者・患者家族の署名を頂き，(3)署名され

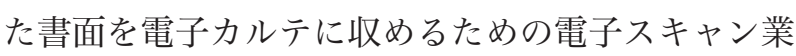
務を行い，(4)場合によっては，手術室入室時のサイ ン・イン業務等で同意書の存在の確認作業が追従す るというょうに，最も手間がかかる部分となる。

IC は，日本語では，「説明と同意」と訳されるが, 実際のプロセスは，説明 $>$ 理解 $>$ 選択 $>$ 納得 $>$ 同意 という5つの段階を踏む必要があると言われる。法 的には，「カルテに記載がないものは，無かったこ とと言われても仕方ない」という観点からすれば, 書面での説明やカルテ記載は重要であり, 説明書を 


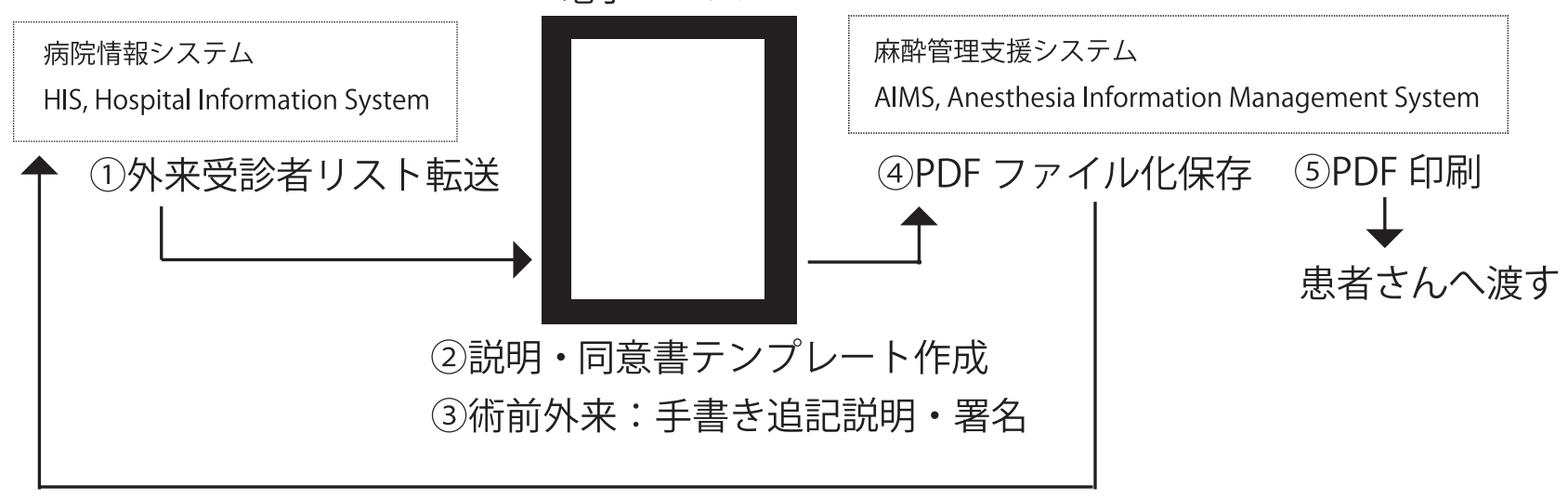

(6)HIS ヘファイル転送保存

図4 デジタルペーパー ${ }^{\mathrm{TM}}$ を用いた術前外来での説明・同意書ワークフロー

インフォームド・コンセント (IC) 取得のプロセスにおいて, デジタルペーパー ${ }^{\mathrm{TM}}$ (Sony 社) (電子ペーパー)を活用するこ とで，病院情報システム (HIS) と麻酔管理支援システム (AIMS) の連携を高めることが可能となる.

デジタルペーパー導入前

(1)説明・同意書テンプレート作成, 印刷

(2)患者・家族の書面署名

(3)電子カルテへの保存（電子スキャン）

(4)手術室サインイン業務：説明・同意書の確認作業

デジタルペーパー導入後
(1)説明・同意書デジタルペーパー作成
(2)患者・家族のデジタルペーパー署名
(3)電子カルテヘPDF ファイル転送>一部印刷（患者用）
(4)手術室サインイン業務：説明・同意書の電子確認作業

図 5 デジタルペーパー ${ }^{\mathrm{TM}}$ 導入前後のワークフローの比較

印刷したり，同意書に署名を頂き，スキャンしたも のを電子カルテに保管したりすることが求められ る. 問診票や, 説明書, 同意書など, 個々の患者に 準備(印刷)が必要となってくる書類が増え，またそ れらをカルテに収めるために電子スキャンの業務が 増える. 最低でも 3 〜 4゚ージの書面が用意され, また電子スキャンが求められ，患者が 1 日 40 名だ
と，160ページにもわたる印刷や電子スキャンが求 められてきた。このような事務業務については，医 療事務補佐や医療事務クラーク等の関わりが最も求 められる部分でもあり, 事務系職員が処理できるフ ローを作成する必要があるが，それにしても大変非 効率的な部分である。

われわれは2016年より，麻酔科外来の説明書，同 
意書に電子タブレットを用いて, 印刷やスキャンの 業務を減らすように努めてきた(図4). Sony, Philips との共同で, Sony 社が開発したデジタルペーパー ${ }^{\mathrm{TM}}$ を用いて, 事前に説明書, 同意書テンプレートを作 成し，個々の患者に対する説明の追記や，医師，患 者の署名は，そのデジタルペーパー ${ }^{\mathrm{TM}}$ 上で電子ペ ンを用いて行う。これにより，莫大な紙の印刷とス キャン業務がなくなり, IC 取得に要する準備作業 時間の短縮が図れるところである(図5)。現在の HIS や AIMS の連携の中に今後はモバイル端末を効率的 に組み込んで, 術前, 術後の外来や病棟業務が関わ る診療記録や説明・同意書の保管などをペーパーレ ス化し, かつ電子検索ソート機能により効率よく,
医療安全・業務効率化につながるように導入してい くとともに，紛失や盜難防止を考えた新たなセキュ リティー対策を確立していくことも重要である.

\section{参考文献}

1) Amaya F, Shimamoto S, Matsuda M, et al. : Preoperative anesthesia clinic in Japan : a nationwide survey of the current practice of preoperative anesthesia assessment. J Anesth $29:$ 175-179, 2015

2）加藤祐子, 石井祥代, 石井真紀ほか：京都府立医科大 学附属病院麻醉術前外来と年次手術統計。京都府立医 科大学雑誌 $124: 13-24,2015$

3）佐和貞治, 権哲, 山崎正記ほか：麻酔術前診察クリニ ックの開設について．京都府立医科大学䧱誌 $119 ： 141-$ 150, 2010

\title{
Medical Safety and Work Flow Efficiency in Perioperative Management
}

\author{
Teiji SAWA
}

\author{
Department of Anesthesiology, Kyoto Prefectural University of Medicine
}

Preoperative management in the anesthesia outpatient clinic has become popular in Japan. At the anesthesia outpatient clinic, it is required to obtain appropriate informed consent from the viewpoint of medical safety for various anesthetic subjects. The procedure to obtain informed consent from the patient and family requires a number of steps such as preparation/consent formulation, printing, signature, digital scanning and so on. We recently introduced a digital paper ${ }^{\mathrm{TM}}$ (Sony, Japan) for acquiring informed consent in the anesthesia outpatient clinic. In this review, we present a new way to perform paperless preoperative anesthesia management.

Key Words : Anesthesia outpatient clinic, Digital paper, Informed consent, Preoperative management, Medical safety

The Journal of Japan Society for Clinical Anesthesia Vol.39 No.3, 2019 